\title{
Thermomechanical and Tribological Properties of SiC/Gr Reinforced Hybrid Aluminum Composite for Disc Brake Application
}

\author{
DWI RAHMALINA \\ Department Mechanical Engineering \\ Universitas Pancasila \\ Srengseng Sawah, Jagakarsa, Jakarta 12640 \\ INDONESIA \\ HENDRI SUKMA \\ Department Mechanical Engineering \\ Universitas Pancasila \\ Srengseng Sawah, Jagakarsa, Jakarta 12640 \\ INDONESIA \\ AMIN SUHADI \\ National Laboratory for Structural Strength Technology \\ Agency for the Assessment and Application of Technology - BPPT \\ Jakarta 10340 \\ INDONESIA
}

\begin{abstract}
The disc brake motorcycle material has been developed by using aluminium matrix composite (AMC) reinforced with matrix particulate ceramic. The composite has many advantages: lightweight, high resistance to wear, and controllable strength by adjusting the reinforcement materials percentage. The main issue is the environmental factor that influences the surface properties of the disc. The research aims to study thermomechanical and tribology characteristics to determine the effect of the environmental factor on the composite's wear-out rate. The disc is made from matrix $\mathrm{Al}_{7} \mathrm{Si}_{6} \mathrm{Mg}_{9} \mathrm{Zn}$ composite matrix with $10 \% \mathrm{SiC}$ and $10 \%$ graphite (v/v). The disc is produced by squeeze casting method and heated for 4 hours at $180{ }^{\circ} \mathrm{C}$ as artificial aging heat treatment. Thermomechanical characteristics are carried out by observing the temperature changes when a load is introduced to the disc. The pin-on-disc method is applied at three different speeds $(60,80$, and $100 \mathrm{rpm}$ ) under the wet and dry surface on the disc for observing the tribological properties. Thermomechanical characteristics of the disc are average braking time is 3.72 seconds, where the average braking distance is 515.8 $\mathrm{cm}$ at speed $40 \mathrm{~km} /$ hour with the average temperature of $46.12{ }^{\circ} \mathrm{C}$. The wear-out rate results are steady, where the highest wear out rate for the dry surface is $0.725 \mathrm{~mm}^{3} / \mathrm{N} . \mathrm{m}$ and $6.133 \mathrm{~mm}^{3} / \mathrm{N} . \mathrm{m}$ for the wet surface at 100 rpm.
\end{abstract}

Key-Words: Aluminium matrix composite; Composite disc brake; Pin-on-disc; Silicon carbide; Tribological Received: March 24, 2021. Revised: September 14, 2021. Accepted: September 24, 2021. Published: October 1, 2021.

\section{Introduction}

In Indonesia, the automotive industry, particularly for motorcycles, is increased significantly where the total number of the motorcycle in Indonesia is more than 120 billion by the end of 2018 [1]. Most of the motorcycle factory is located in Indonesia and producing motorcycle for both local and overseas market. The increase in demand is followed by technology development for the motorcycle to achieve a better comfortability, a higher safety and a better quality of its measurement and also focusing on sustainable manufacturing with a lower energy consumption for the production process [2]-[4]. One of the critical parts for both safety and comfortability is the braking system. The current generation of motorcycles is obligated to use a disc brake system for the front and rear wheel.

The disc's basic requirements for the braking system can stand with corrosion due to environmental effect [5], low heat generation during braking [6], 
the low wear-out rate where at the same time should produce sufficient friction for the brake pad [7]. The disc is generally made from cast iron and stainless steel, where it can meet the minimum requirements, but it has some significant drawbacks; heavy, high temperature during braking, and required enormous energy for production [8]. Further research is required to overcome the drawbacks of the disc, and it can be done by developing an alternative option for the material of the disc. Among the ideal candidate for the disc material, aluminium matrix composites are suitable options by considering the basic requirements of the disc and the manufacturing process where it can be considered economically feasible and environmentally friendly with minimum less energy to produce it [9].

Aluminium alloy is a lightweight material that is sufficient to be used for disc brakes. The mechanical strength of the aluminium can be improved by alloying with different material for reinforcement like silicon carbide (SiC) and graphite [10]. Matrix composites add two or more materials with different properties to obtain the best matrix-material as a new composite. In this case, the nature of $\mathrm{SiC}$ is brittle, and graphite is ductile, then needs to be found the ideal portion of the material that can improve the overall properties as one composite without shortcoming. The main advantages of aluminium matrix composites for disc brake compared to cast iron and stainless steel are better mechanical strength and stiffness, a proper thermal distribution that reduces high-temperature braking and low thermal expansion, and steady wear out, lightweighted, and high corrosion resistance [11]-[13].

In order to improve the disc quality for the braking system on a motorcycle, it needs to develop a new material that can overcome the drawbacks of the conventional disc on the braking system [14]. This research is focused on the development of material for disc braking system by using aluminium matrix composites $\left(\mathrm{Al}_{7} \mathrm{Si}_{9} \mathrm{Zn}_{6} \mathrm{Mg}\right)$ by adding ceramic particulate of $\mathrm{SiC}(10 \%)$ and graphite $(10 \%)$ as reinforcement. Aluminum composite for disc brake is highly recommended to substitute the conventional disc brake material which mainly using cast-iron [15]. The main drawbacks for aluminum as disc brake material are low mechanical behaviour and high wear-out rate. The addition of $30 \%$ alumina particles able to improve the mechanical strength of the aluminum matrix composite for disc brake [16]. Another study also proposed reinforcement material by using clay to improve the aluminum matrix composite as disc brake. It shows that the addition of 15 $\mathrm{wt} \%$ of clay able to reduce the wear out rate of the composite while maintaining the mechanical strength during the test.

The addition of reinforcement material able to improve the mechanical strength of the aluminum composite and decreasing the wear out rate. Unfortunately, most of the study focused on the addition of non-ceramic material as the reinforcement. Ceramic material is recommended as the reinforcement material for aluminum composite as disc brake since it promotes a better mechanical strength and temperature distribution during braking [17]-[19]. In this study, a new approach for developing aluminum matrix composite by using $\mathrm{SiC}$ and graphite is proposed. SiC and graphite are considered as low cost material to be used as reinforced material with superior mechanical performance and suitable to be used for aluminum matrix composite [20]-[22].

Though the addition of $\mathrm{SiC}$ and graphite is highly recommended for aluminum matrix composite, there is limited study which focused on the combination effect of the material on mechanical and wear out characteristic for aluminum matrix composite. Therefore, this study focused on the performance of aluminum matrix composite by using $\mathrm{SiC}$ and graphite as reinforcement material. The disc produced by the squeeze casting method will be tested to study the disc performance using the thermomechanical test. To support the finding, hardness test, macro and microstructure observation before and after tests are conducted as well [23]. The thermomechanical test is intended to find the wear-out rate of the disc and can be used as important information for the developed material [24].

\section{Materials and Methods}

The ingot material for the disc is $\mathrm{Al}_{7} \mathrm{Si}_{9} \mathrm{Zn}_{6} \mathrm{Mg}$ reinforced with ceramic particulate $10 \% \mathrm{SiC}$ and $10 \%$ graphite (volume/volume fraction). The disc is produced by using squeeze casting and followed with heat treatment for mechanical strengthening. The aluminium matrix alloy is melted at an induction furnace at temperature $850{ }^{\circ} \mathrm{C}$. The ceramic particulate ( $\mathrm{SiC}$ and Graphite with the average size of 0.45 $\mu \mathrm{m})$ is preheated in the furnace at a temperature of $1,000{ }^{\circ} \mathrm{C}$ for 1 hour to improve the wettability. It is then poured into an aluminium matrix composite and stirred at a speed of 5,000 rpm for 1 minute. The composite is poured into mold that has preheated at $300{ }^{\circ} \mathrm{C}$ for 30 minutes. The squeeze casting is done by applying pressure $30 \mathrm{MPa}$ to the mold at semi-solid temperature (when the mold at temperature $590-610^{\circ} \mathrm{C}$ ). After reaching the ambient temperature, the disc is taken from the mold and then proceed into three heat treatment process: solution 
heat treatment at temperature $350{ }^{\circ} \mathrm{C}$ for 1 hour, quenching under and aging treatment at temperature $180{ }^{\circ} \mathrm{C}$ for 4 hours.

The various test follows the produced disc brake: observation for the chemical composition using a spectrometer under the ASTM E1251 standard and surface hardness test. Thermomechanical performance is carried out to find the temperature versus load function. The thermomechanical test is done as followed: the disc is attached to a spinning shaft with various speeds then the braking force is applied through the hydraulic braking system until the disc is stopped. The temperature change on the disc from the test, the braking distance, and braking time are obtained and meet the SNI 4404: 2008 standard. Tribological characteristic of the disc is observed as the wear-out rate of the disc under various speed and surface conditions (ASTM G99-04) with a specific load of $3.14 \mathrm{~kg}$. The speed variations are 60 , 80 , and $100 \mathrm{rpm}$, where surface conditions are dry at ambient temperature $\left(30^{\circ} \mathrm{C}\right)$ and WET. The microstructure of each test is observed by using an optical and scanning electron microscope.

\section{Results}

\subsection{Chemical Composition}

The disc is made from aluminium matrix composites of $\mathrm{Al}_{7} \mathrm{Si}_{9} \mathrm{Zn}_{6} \mathrm{Mg}$ with ceramic particulate $10 \%$ $\mathrm{SiC}$ and $10 \%$ graphite (v/v), and before conducting the physical test, it needs to be found the chemical composition of the disc. The chemical observation found that the increased amount of $\mathrm{Zn}$ and it might be caused by crucible residual. It is also found that the amount of $\mathrm{Fe}, \mathrm{Cu}, \mathrm{Mn}$, and $\mathrm{Cr}$ on the disc but a low concentration can be neglected to affect the mechanical properties of the aluminium matrix composites. Table 1 shows the average chemical content of the disc.

Table 1. Chemical composition test from the disc

\begin{tabular}{clllllll}
\hline $\begin{array}{l}\text { Meas- } \\
\text { urement } \\
\text { Points }\end{array}$ & $\mathrm{Al}$ & $\mathrm{Si}$ & $\mathrm{Fe}$ & $\mathrm{Cu}$ & $\mathrm{Mn}$ & $\mathrm{Zn}$ & $\mathrm{Cr}$ \\
\hline 1 & 74.5 & 8.39 & 0.0784 & $1 \times 10^{-3}$ & $1 \times 10^{-3}$ & 5.98 & 11.0 \\
2 & 73.6 & 8.23 & 0.0816 & $1 \times 10^{-3}$ & $1 \times 10^{-3}$ & 6.06 & 12.0 \\
3 & 75.3 & 7.92 & 0.0682 & $1 \times 10^{-3}$ & $1 \times 10^{-3}$ & 6.04 & 10.6 \\
Average & 74.4 & 8.18 & 0.0761 & $1 \times 10^{-3}$ & $1 \times 10^{-3}$ & 6.03 & 11.2 \\
\hline
\end{tabular}

The result from Table 1 shows each composition at a different measurement point has small differences. Thus, it can be said that the material of the disc is uniform, and the casting process of the disc is done correctly.

\subsection{Thermomechanical Characterization}

The thermomechanical characteristics of the disc brake made from $\mathrm{Al}_{7} \mathrm{Si}_{9} \mathrm{Zn}_{6} \mathrm{Mg}$ reinforced with ceramic particulate $10 \% \mathrm{SiC}$, and $10 \%$ graphite were tested to find the temperature on the disc that occurs due to loading during braking. The test using a speed of $40 \mathrm{~km} /$ hour per SNI 4404:2008 standards. There are two braking models, static and dynamic braking.

Table 2. Detail of the load on braking system

\begin{tabular}{lll}
\hline \multicolumn{1}{c}{ Parameters } & Symbol & \multicolumn{1}{c}{ Value } \\
\hline $\begin{array}{l}\text { Force ratio from the brake lev- } \\
\text { er }\end{array}$ & $\mathrm{K}$ & 6 \\
$\begin{array}{l}\text { Force from the brake lever } \\
\begin{array}{l}\text { The hydraulic pressure at mas- } \\
\text { ter cylinder }\end{array}\end{array}$ & $\mathrm{FK}$ & $88.6 \mathrm{~N}$ \\
$\begin{array}{l}\text { Force applied by the brake pad } \\
\text { to the disc }\end{array}$ & $\mathrm{F}_{\mathrm{p}}$ & $167.2 \mathrm{~N} / \mathrm{cm}^{2}$ \\
The braking friction force & $\mathrm{F} \mu$ & $0.46 \mathrm{kN}$ \\
\hline
\end{tabular}

The static braking is performed when the motorcycle is at rest, and the front wheel is driven by an external driver (electric motor), and at this point, the disc has not experienced inertia load from the motorcycle. The dynamic braking is taken by measuring the length and duration of the braking force to stop the motorcycle at a speed of $40 \mathrm{~km} / \mathrm{h}$. The applied force for braking is steady, then the temperature of the disc, length, and duration is obtained precisely. The details of the load on the braking system are given in Table 2 .

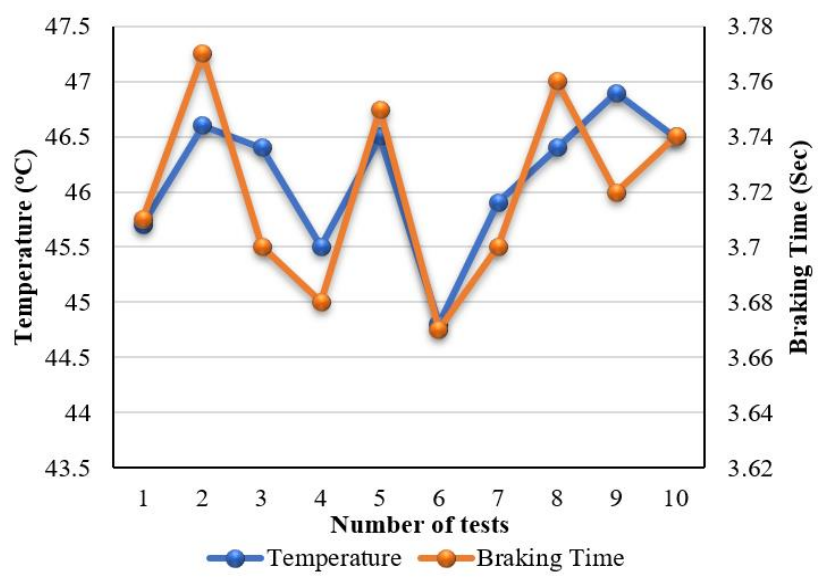

Fig. 1: The results of the static braking test

From Table 2, it can be seen that the braking force is $1,52 \mathrm{kN}$ while the friction force is $0.46 \mathrm{kN}$ at a speed of $40 \mathrm{~km} / \mathrm{hour}$. The temperature on the disc during braking and braking timing is obtained from the static test. The distance of the braking is obtained from the dynamic test. The static test is 
repeated ten times to obtain more precise the average temperature and braking time. Figure 1 shows the graphical results of the static test. After applying the braking force of $1,52 \mathrm{kN}$ at speed $40 \mathrm{~km} / \mathrm{hour}$, the average temperature on the disc is $46.12{ }^{\circ} \mathrm{C}$ with an average braking of 3.72 seconds.

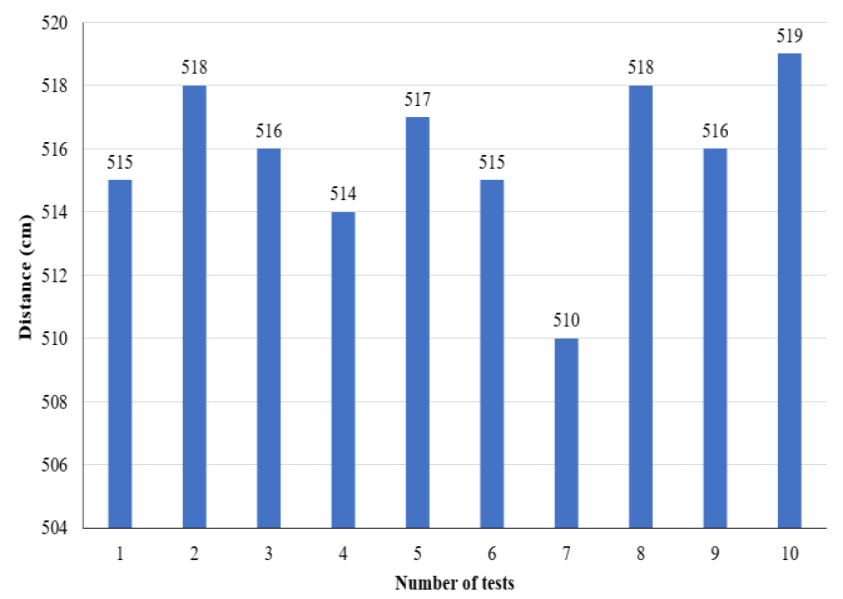

Fig. 2: Braking Distance Testing Results.

The dynamic test was conducted and also repeated ten times. The dynamic braking force from the friction force is applied and make the motorcycle stopped. The friction force is $0.46 \mathrm{kN}$, and the average braking distance is $515.8 \mathrm{~cm}$. Figure 2 shows the graphical dynamic test for the disc. Since the force has been applied to the disc from the static and dynamic test, the friction and temperature affect the morphological and the strength of the disc. It needs to find the effect of the test on the disc. To make a fair comparison, the disc is tested before and after the braking test. From this perspective, it can find the effect of the thermomechanical test and also the properties of the disc to absorb the force that is applied for braking.

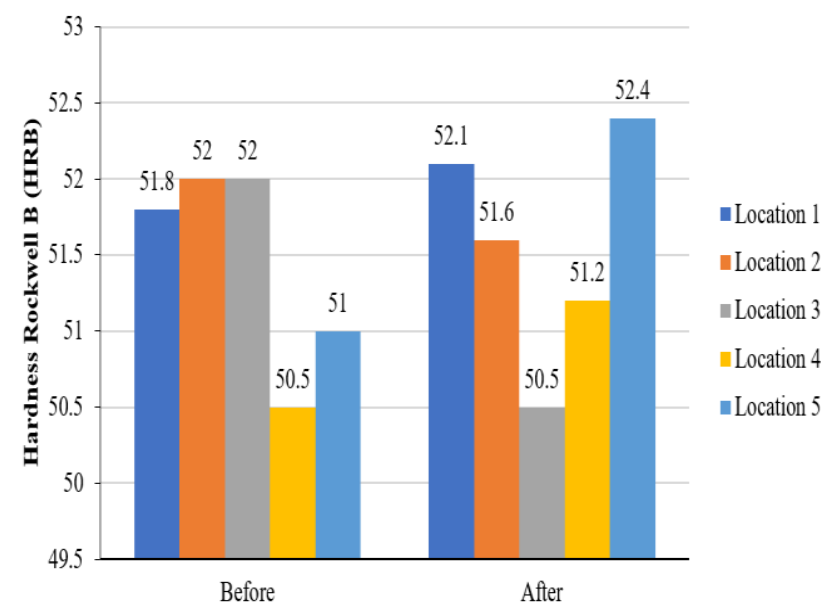

Fig. 3: The hardness test results of the composite
Both samples were characterized by applying force $0.98 \mathrm{kN}$ randomly using ball indenter (diameter $1 / 16$ inch) and the result is shown in Figure 3. The force from the indenter is applied at five different positions on the disc. The average hardness number of the disc before and after the thermomechanical test is $51.46 \mathrm{HRB}$ and 51.56. The differences of the hardness number on the disc considered low where it can be said that the effect on the braking load does not change the strength of the disc. It can be said that the developed matrix aluminium matrix composites by adding ceramic particulate show desirable performance.

\subsection{Wear Out Characteristic}

Figure 4 shows the wear-out rate of the disc where the test is conducted on the dry surface. The wearout rate occurs at $60 \mathrm{rpm}$ with an abrasion volume of $79.21 \mathrm{~mm}^{3}$, with the wear-out rate of $2.018603466 \mathrm{~mm}^{3} / \mathrm{N} . \mathrm{m}$. At speed $80 \mathrm{rpm}$, it is obtained the abrasion volume is $237.65 \mathrm{~mm}^{3}$ where the wear-out rate $3.907303278 \mathrm{~mm}^{3} / \mathrm{N} . \mathrm{m}$.
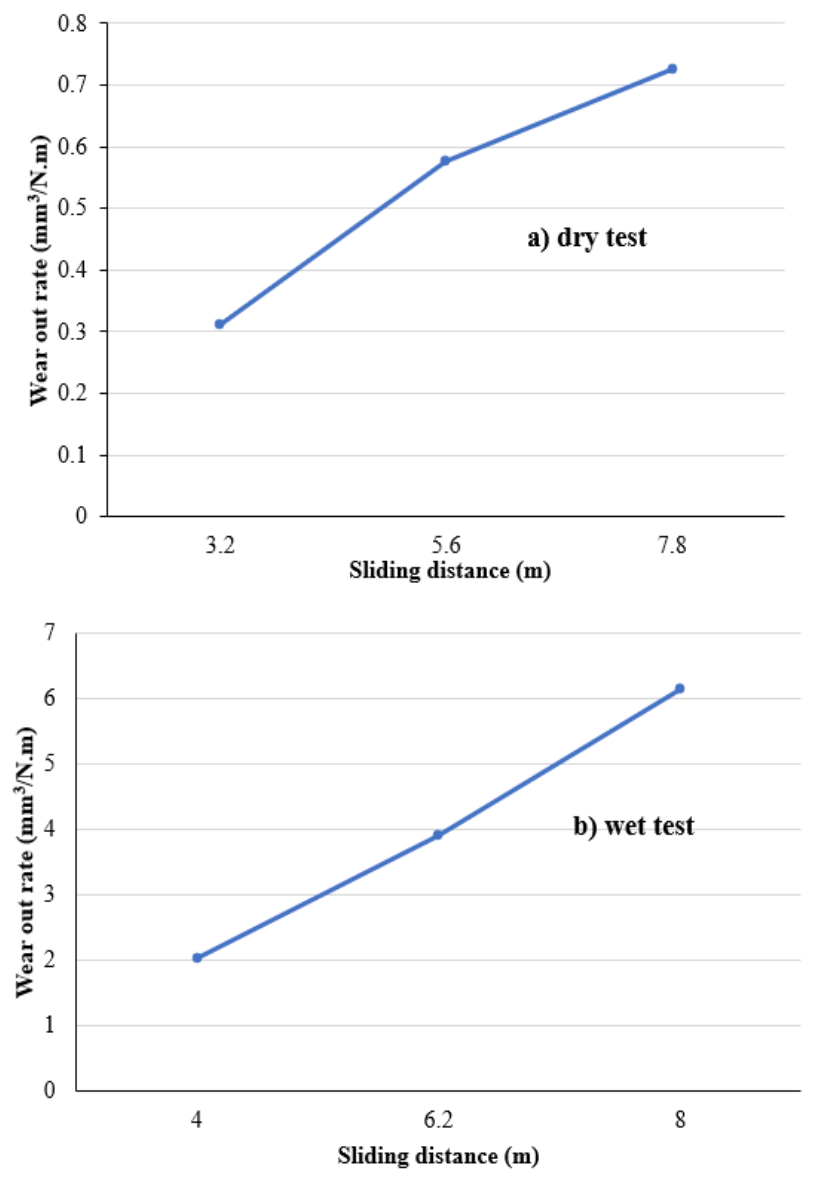

Fig. 4: The wear-out rate of the disc during dry (a) and wet (b) test 
For the speed at $100 \mathrm{rpm}$, it is obtained the abrasion volume is $475.3 \mathrm{~mm}^{3}$ with the wearout rate $6.132982361 \mathrm{~mm}^{3} / \mathrm{N} . \mathrm{m}$. The wear-out rate of the developed matrix aluminium matrix composites from $\mathrm{Al}_{7} \mathrm{Si}_{6} \mathrm{Mg}_{9} \mathrm{Zn}$ composite matrix with $10 \% \mathrm{SiC}$ and $10 \%$ graphite is increased linearly to the sliding distance where the increase of the sliding distance will increase the wear-out rate.

\subsection{Morphological Observation}

Metallographic observations in Figure 5 (a) show the surface of the disc brake before the thermomechanical test. It shows slight scratches due to the machining process after the thermomechanical test is carried out with the braking force of $1.52 \mathrm{kN}$, a friction force of $0.46 \mathrm{kN}$, and an average temperature change of $46.12{ }^{\circ} \mathrm{C}$ shown in Figure 5 (b) shows that there is a deep scratch caused by friction between the disc brake and disc pad. The applied braking force of $1.52 \mathrm{kN}$ and the heat generation during the braking test (with the average temperature of $46.12{ }^{\circ} \mathrm{C}$ ) that occurs on the thermomechanical test does not change the microstructure of the disc brake made of matrix aluminium matrix composites.
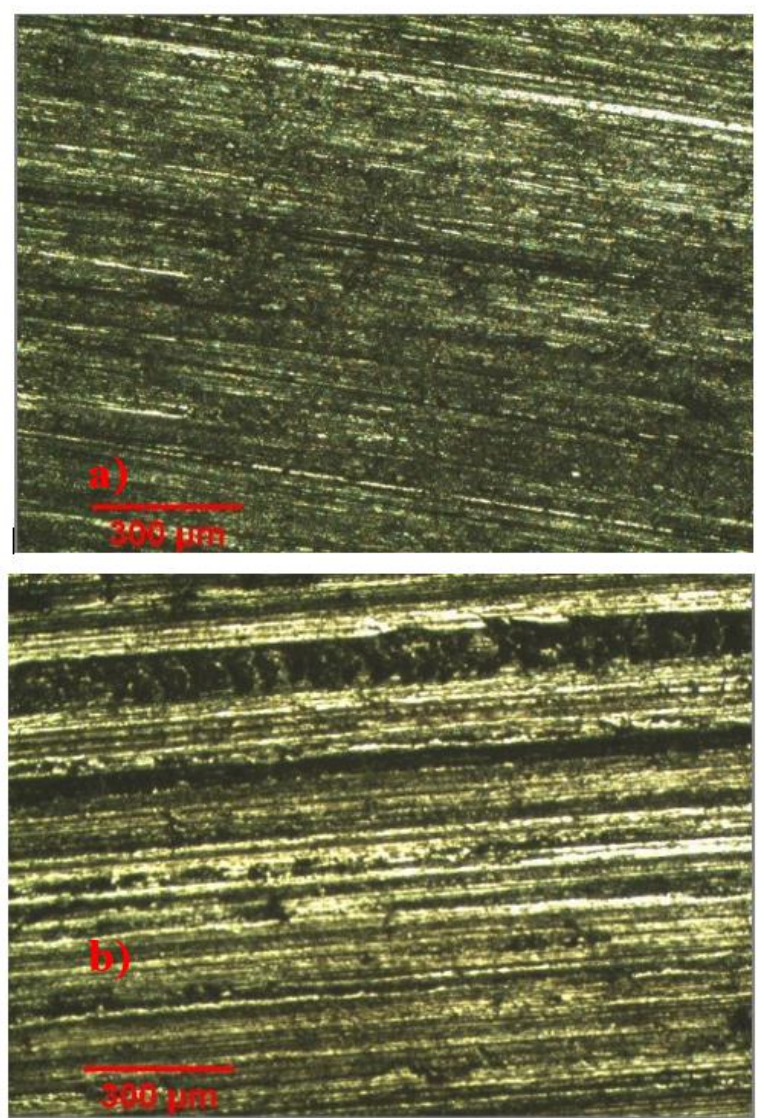

Fig. 5: The morphological surface of the disc brake before (a) and after (b) thermomechanical test
The dominant structure is globular with little dendrite structure, as shown in Figure 6. The porosity level occurs due to the slow process of pouring molten metal into the mold and quick freezing that trapped the air. It is caused by the addition of ceramic particulate for reinforcement with a high concentration (10\% of $\mathrm{SiC}$ and $10 \%$ of graphite). Thermomechanical testing does not cause defects in the disc brake. It just affects the surface of the disc (scratches) which is normal for disc since the braking force is applied and make friction on the disc. The scanning electron microscope observation (SEM) are conducted to observe the micro and macro structures on the surface. The trail width on the surface is affected from the pin on disk test during wear out rate measurement under different surface conditions and dry and wet surface with various speeds.
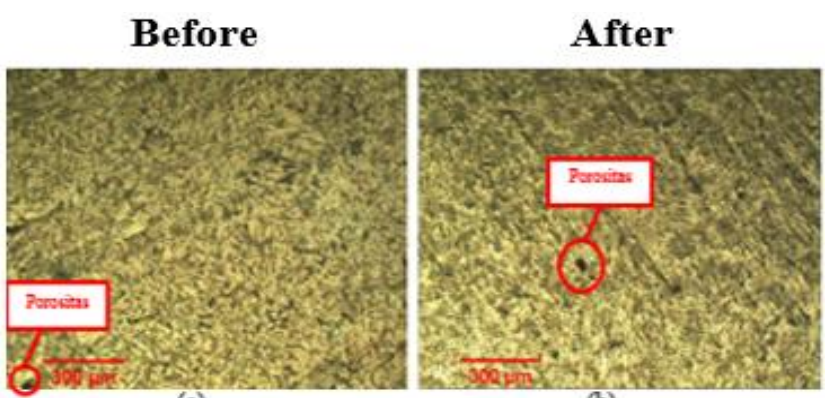

(a)
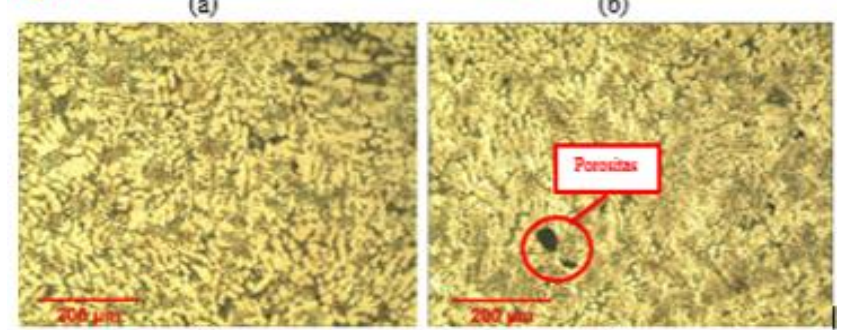

(c)

(d)

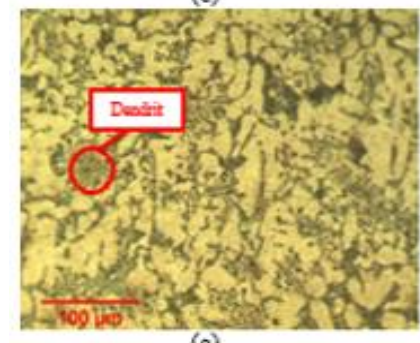

(e)

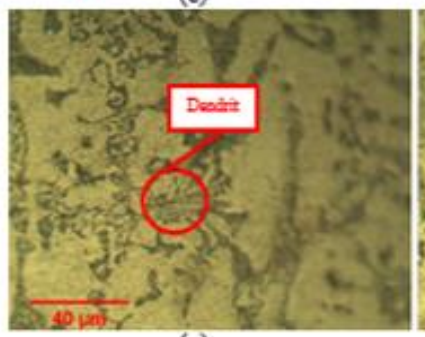

(g)

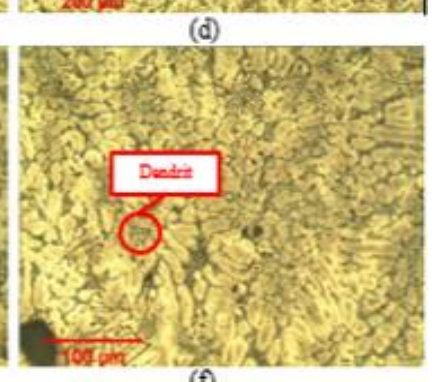

(f)

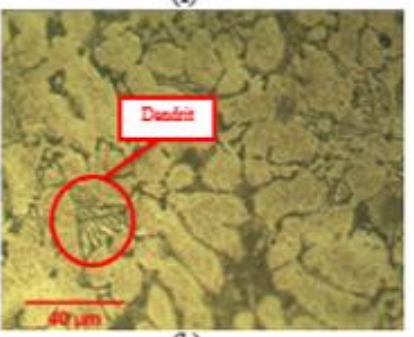

(h)

Fig. 6: Surface structure for the disc brake before and after thermomechanical test with magnification: (a-b) 50x ; (c-d) 100x ; (e-f) 200x ; (g-h) 500x. 
Figure 7 shows the SEM result for the macrostructure observation of the sample. Figure $7 a-7 c$ shows the SEM result of the sample tested under the dry surface. Under 30x magnification (Figure 7a), the trace of the wear out on the surface has a width of $1.413 \mathrm{~mm}$. For the sample under the wet surface test (Figure $7 \mathrm{~d}$ ), with the same magnification, the trace of the wear out on the surface is wider $(1.877$ $\mathrm{mm}$ ). The microstructure for both samples (dry and wet, figure $7 \mathrm{~b}$ and $7 \mathrm{e}$ ) has an identical pattern where particle clumps are observed. At $150 \mathrm{x}$ magnification (Figure 7c and 7f), both samples of the groove from the wear out the test are observed clearly. The research finding is related to another research conducted by Satryo Soemantri [25] where the rate of wear out increases due to the presence of water content on the surface. The presence of water increases the friction rate between disc brake and disc pad in order to maintain the braking performance, if the wear out rate is the same as dry surface, the braking performance will decrease and sliding distance increased which is dangerous for high response braking for motorcycle.
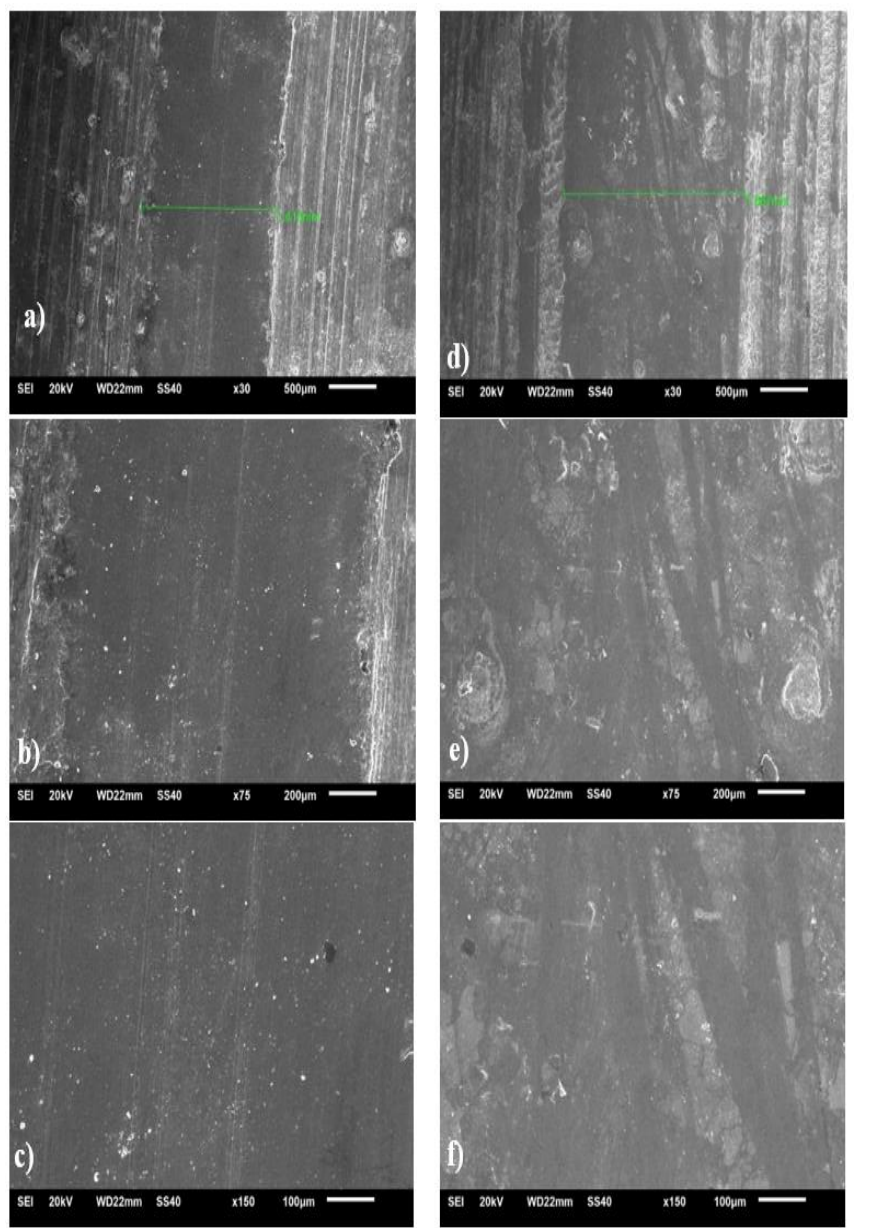

Fig. 7: The morphological surface of the disc brake before (a) and after (b) thermomechanical test

\section{Discussion}

The aluminium matrix composite with ceramic particulate has a significance improvement based on the static and dynamic test. The average temperature during braking test is $46.12{ }^{\circ} \mathrm{C}$ which indicates a suitable heat generation during braking. It shows the applied force for the braking can be absorbed sufficiently by the disc which improve the braking response. It also proved by the average braking time which only 3.72 seconds. A responsive braking system without generating too much heat on the disc is desirable which help to improve the durability of the disc brake. According to those parameters, there is no reduction on the braking performance from the presence of ceramic particulate for the developed disc which is usually occurred for the typical disc brake [26].

The addition of ceramic particulate helps to maintain the hardness level of the disc brake. The average hardness level for the disc before and after braking test is 51.46 and 51.56, which illustrates an adequate hardiness level. An excessive increasing for the hardness level after braking test is unacceptable since the disc can be fractured suddenly during the braking [27]. The change in hardness level also affect the braking distance. According the Figure 2, the braking distance is fluctuated as the result of the change in hardness level after repeated braking test. Even though, the fluctuation is nearly low, which also shows a noticeable performance for the braking system after repeated test [28].

The wear out characteristic varies between dry and wet test. As seen in Fig. 4, the wear out rate is increased significantly for wet test. The environment effect does not influence significantly for the braking performance which can be observed from the sliding distance between dry and wet test. It proves that the composite able to maintains the braking performance under wet surface [29]. Morphological observation is also supported that the composite able to maintain its performance without significant change after thermomechanical test. Overall, the proposed composite able to meet the ideal criteria for disc brake in motorcycle and since it uses aluminum as the main material, the cost production can be reduced significantly and can be considered as an alternative for disc brake material for motorcycle.

\section{Conclusion}

Based on the thermomechanical test result for the disc made of aluminium matrix composites with aluminium-based alloy $\left(\mathrm{Al}_{7} \mathrm{Si}_{9} \mathrm{Zn}_{6} \mathrm{Mg}\right)$ and ceramic 
particulate (10\% $\mathrm{SiC}$ and $10 \%$ graphite) able to strengthen the mechanical structure of the disc. The average temperature on the disc is $46.12{ }^{\circ} \mathrm{C}$, and it is considered low enough compared to the disc-based of cast-iron and stainless. Furthermore, the braking response is relatively good, with a braking time of 3.72 seconds with a braking distance of $515.8 \mathrm{~cm}$. The hardness test showed the average hardness number for the disc before thermomechanical testing is $51.46 \mathrm{HRB}$, and it increased slightly to 51.56 HRB after the thermomechanical test. It can be said that the test does not affect the disc while it is good evidence that the developed disc aluminium matrix composites with ceramic particulate as reinforcement have good thermomechanical characteristics, and it is suitable to be applied for the disc braking system on a motorcycle. The overall conclusions are:

1. The average hardness number (HRA) for the disc is 52.6, while the minimum and maximum values are 51 HRA and 54.6 HRA, respectively.

2. The wear-out rate of the disc is dependent on the rotational speed and surface condition (dry or wet), and the lowest wear out rate is found to be $0.310580517 \mathrm{~mm}^{3} / \mathrm{N} . \mathrm{m}$, and the highest is $0.724692222 \mathrm{~mm}^{3} / \mathrm{N} . \mathrm{m}$

3. From the SEM observation, it is found that there is matrix aluminium $\alpha$, eutectic for $\mathrm{Si}, \mathrm{SiC}$, and graphite, and also there are small porosity on the surface, which might be caused by the material handling and quenching process

4. The trace of the wear out for the disc with the wet surface is found to be wider than the dry surface, where the trace is $1.413 \mathrm{~mm}$ and $1.887 \mathrm{~mm}$ for the wet surface.

Though the overall performance of the proposed aluminum matrix composite shows an excellent mechanical strength and wear out rate, further research is still needed, particularly for life cycle assessment of the proposed material. Further research is also needed to test the disc brake under high braking force for high-speed motorcycle.

\section{References:}

[1] Badan Pusat Statistik, "Total Motorcycle in Indonesia by 2018,” 2019.

[2] I. Ismail, R. A. Rahman, G. Haryanto, and E. A. Pane, "The Optimal Pitch Distance for Maximizing the Power Ratio for Savonius Turbine on Inline Configuration," Int. J. Renew. Energy Res., vol. 11, no. 2, pp. 595-599, 2021.

[3] Ismail, J. John, E. A. Pane, R. Maulana, R. A. Rahman, and A. Suwandi, "Experimental evaluation for the feasibility of test chamber in the open-loop wind tunnel," WSEAS Trans. Fluid
Mech., vol. 16, pp. 120-126, 2021.

[4] Ismail, E. A. Pane, G. Haryanto, T. Okviyanto, and R. A. Rahman, "A Better Approach for Modified Bach-Type Savonius Turbine Optimization," Int. Rev. Aerosp. Eng., vol. 14, no. 3, pp. 159-165, 2021.

[5] M. Tirovic, N. Sergent, J. Campbell, P. Roberts, and R. Vignjevic, "Structural analysis of a commercial vehicle disc brake caliper," Proc. Inst. Mech. Eng. Part D J. Automob. Eng., vol. 226, no. 5, pp. 613-622, 2012.

[6] P. Grzes, "Maximum temperature of the disc during repeated braking applications," $A d v$. Mech. Eng., vol. 11, no. 3, pp. 1-13, 2019.

[7] J. Wahlström, A. Söderberg, L. Olander, U. Olofsson, and A. Jansson, "Airborne wear particles from passenger car disc brakes: A comparison of measurements from field tests, a disc brake assembly test stand, and a pin-on-disc machine," Proc. Inst. Mech. Eng. Part J J. Eng. Tribol., vol. 224, no. 2, pp. 179-188, 2010.

[8] J.-S. Yoo, "Static Characterization of Carbon Carbon Brake Disk," J. Compos. Mater., vol. 36, no. 18, pp. 2135-2151, 2002.

[9] S. Sharma, T. Nanda, and O. P. Pandey, "Effect of elevated temperatures and applied pressure on the tribological properties of LM30/sillimanite aluminium alloy composites," J. Compos. Mater., vol. 53, no. 11, pp. 1521-1539, 2019.

[10] R. Singh, I. Singh, R. Kumar, and G. S. Brar, "Waste thermosetting polymer and ceramic as reinforcement in thermoplastic matrix for sustainability: Thermomechanical investigations," J. Thermoplast. Compos. Mater., pp. 1-13, 2019.

[11] S. B. Porlekar, P. S. G. Bhatwadekar, and P. G. R. Kulkarni, "Design, analysis and optimization of brake disc made of composite material for a motor cycle," Int. J. Res. Publ. Eng. Technol., vol. 3, no. 3, pp. 63-69, 2017.

[12] Y. V. N. Chandana and K. V. P. Reddy, "Transient Thermal Analysis of AlSiCp Composite Disc Brake," Int. J. Comput. Eng. Res., pp. 29-33, 2017.

[13] R. C. Samudra, H. Seputro, I. L. K, and A. F. A, "Thermal Characteristics of Matrix Composites of Aluminum - Ash Base Coal after T6 Heat Treatment," Pros. SNTTM XVI, vol. XVI, pp. 8790, 2017.

[14] S. Veličković, B. Stojanović, M. Babić, and I. Bobić, "Optimization of tribological properties of aluminum hybrid composites using Taguchi design," J. Compos. Mater., vol. 51, no. 17, pp. 2505-2515, 2017.

[15] I. Romanov, E. Chernyshov, and A. Romanov, "Assessment of the possibility for substituting cast iron in vehicle brake disc with AluminumBased Metal-matrix composite material produced by internal oxidation," Mater. Today Proc., vol. 19, no. 09, pp. 2125-2128, 2019. 
[16] F. Ahmad, S. H. J. Lo, M. Aslam, and A. Haziq, "Tribology behaviour of alumina particles reinforced aluminium matrix composites and brake disc materials," Procedia Eng., vol. 68, no. 0, pp. 674-680, 2013.

[17] L. Gorjan et al., "Ceramic protection plates brazed to aluminum brake discs," Ceram. Int., vol. 42, no. 14, pp. 15739-15746, 2016.

[18] H. Seo, J. Park, Y. C. Kim, J. J. Lee, and H. Jang, "Effect of disc materials on brake emission during moderate-temperature braking," Tribol. Int., vol. 163, no. May, p. 107185, 2021.

[19] V. Casalegno et al., "Study on the joining of ceramic matrix composites to an $\mathrm{Al}$ alloy for advanced brake systems," Ceram. Int., vol. 47, no. 16, pp. 23463-23473, 2021.

[20] K. Harshavardhan, S. Nagendran, A. Shanmugasundaram, S. R. Pravin Sankar, and K. Sai Kowshik, "Investigating the effect of reinforcing $\mathrm{SiC}$ and graphite on aluminium alloy brake rotor using plasma spray process," Mater. Today Proc., vol. 38, no. xxxx, pp. 2706-2712, 2020.

[21] C. Pinca-Bretotean, R. Bhandari, C. Sharma, S. K. Dhakad, P. Cosmin, and A. K. Sharma, "An investigation of thermal behaviour of brake disk pad assembly with Ansys," Mater. Today Proc., 2021.

[22] L. JIANG et al., "Fabrication, microstructure, friction and wear properties of $\mathrm{SiC} 3 \mathrm{D} / \mathrm{Al}$ brake disc-graphite/SiC pad tribo-couple for highspeed train," Trans. Nonferrous Met. Soc. China (English Ed., vol. 29, no. 9, pp. 1889-1902, 2019.

[23] S. Singh, G. Singh, L. Kumar, and S. Singh, "Microstructural analysis and tribological behavior of aluminum alloy reinforced with hybrid alumina/nanographite particles," Proc. Inst. Mech. Eng. Part J J. Eng. Tribol., vol. 229, no. 5, pp. 597-608, 2015.

[24] M. Akbari, M. H. Shojaeefard, P. Asadi, and A. Khalkhali, "Wear and mechanical properties of surface hybrid metal matrix composites on $\mathrm{Al}-\mathrm{Si}$ aluminum alloys fabricated by friction stir processing," Proc. Inst. Mech. Eng. Part L J. Mater. Des. Appl., vol. 233, no. 5, pp. 790-799, 2019.

[25] Dahlan and S. S. B, "Uji Coba Profil Aus Untuk Mengurangi Keausan Flens Roda Gerbong Kkbw Ka Babaranjangk," Mesin, vol. 17, no. 1. pp. 1-8, 2002.

[26] R. Balaji, M. Nadarajan, A. Selokar, S. S. Kumar, and S. Sivakumar, "Modelling and analysis of Disk Brake under Tribological behaviour of AlAl2O3 Ceramic Matrix Composites/Kevlar® 119 composite/C/Sic-Carbon Matrix Composite/CrNi-Mo-V steel.," Mater. Today Proc., vol. 18, pp. 3415-3427, 2019.

[27] G. Bian and H. Wu, "Friction and surface fracture of a silicon carbide ceramic brake disc tested against a steel pad," J. Eur. Ceram. Soc., vol. 35, no. 14, pp. 3797-3807, 2015.

[28] K. Vinoth Babu, S. Marichamy, P. Ganesan, D. Madan, M. Uthayakumar, and T. P. D. Rajan, "Processing of functionally graded aluminum composite brake disc and machining parameters optimization," Mater. Today Proc., vol. 21, no. xxxx, pp. 563-567, 2020.

[29] L. B. Shi, F. Wang, L. Ma, Q. Y. Liu, J. Guo, and W. J. Wang, "Study of the friction and vibration characteristics of the braking disc/pad interface under dry and wet conditions," Tribol. Int., vol. 127, pp. 533-544, 2018.

\section{Contribution of Individual Authors to the Creation of a Scientific Article (Ghostwriting Policy)}

Dwi Rahmalina: conceptualization and methodology

Hendri Sukma: Investigation

Amin Suhadi: resources.

\section{Sources of Funding for Research Presented in a Scientific Article or Scientific Article It- self \\ The authors are grateful to The State Ministry of Research, Technology and Higher Education, The Republic of Indonesia by funding this work under the PTUPT Incentive 2019-2020.}

\section{Creative Commons Attribution License 4.0 (Attribution 4.0 International, CC BY 4.0)}

This article is published under the terms of the Creative Commons Attribution License 4.0 https://creativecommons.org/licenses/by/4.0/deed.en US 